\title{
Transcriptional modulation of HIV-1C LTR promoter
}

\author{
Anand Singh", Pradeep Ramalingam, Jayanth Kumar Palanichamy, Mohita Bhagat, Muzaffer Ahmad Kassab, \\ Subrata Sinha, Parthaprasad Chattopadhyay \\ From First International Science Symposium on HIV and Infectious Diseases (HIV SCIENCE 2012) \\ Chennai, India. 20-22 January 2012
}

\section{Background}

All current anti-HIV1 therapies target the viral proteins or RNA; however targeting HIV1 at the transcriptional level of the integrated provirus has been less explored. In India, AIDS is commonly caused by HIV-1C compared to HIV-1B in developed countries. HIV1-5'LTR acts as a promoter and shows sequence variation among different clades. Transcriptional gene silencing (TGS) is a method wherein dsRNA targeting the promoter/ enhancer of a gene are used to down regulate its expression.

\section{Methods}

We used SiHa cell line stably expressing a bi-cistronic reporter system (5'LTR-SEAP-IRES-EGFP), in which secreted alkaline phosphatase (SEAP) and enhanced green fluorescent protein (EGFP) are expressed under 5'LTR of HIV-1B/C. The cell line was transfected with different dsRNAs (S1-S6) targeting the core promoter/ enhancer of HIV-1C LTR to induce TGS. Screening for decreased transcription was done using real-time PCR (mRNA expression of SEAP and EGFP), fluorescence microscopy (EGFP) and flow cytometry (EGFP).

\section{Results}

After single or multiple (thrice) transfection of dsRNAs, we identified one dsRNA (S4) which showed consistent and significant down regulation of both SEAP (44\% \& $68 \%$ respectively) and EGFP $(40 \% \& 65 \%)(\mathrm{p}<0.001$ in both cases) mRNA levels. This reporter down regulation was also confirmed by studying EGFP expression using fluorescence microscopy and flowcytometry which also showed a significant fall after S4 transfection.

\footnotetext{
* Correspondence: anandam84@gmail.com

All India Institute of Medical Sciences (AlIMS), New Delhi, India
}

\section{Conclusion}

TGS usually involves epigenetic modifications like DNA methylation/histone methylation at the targeted region and induces long term suppression of gene expression. So targeting of the HIV-1C LTR by dsRNA can be used as a therapeutic modality in the future.

Published: 4 May 2012

doi:10.1186/1471-2334-12-S1-O6

Cite this article as: Singh et al:: Transcriptional modulation of HIV-1C LTR promoter. BMC Infectious Diseases 2012 12(Suppl 1):O6.

Submit your next manuscript to BioMed Central and take full advantage of:

- Convenient online submission

- Thorough peer review

- No space constraints or color figure charges

- Immediate publication on acceptance

- Inclusion in PubMed, CAS, Scopus and Google Scholar

- Research which is freely available for redistribution 